\title{
Effects of Mystical Literature on Islamic Architecture of Iran in Ilkhanid and Timurid Era
}

\author{
Hamed Zohrehvand", Manouchehr Foroutan, Mohammadmehdi Goodarzisoroush \\ Department of Architecture, Hamedan Branch, Islamic Azad University, Hamedan, Iran
}

Email address:

hamed.zohrevand@gmail.com (H. Zohrehvand), m.foroutan@iauh.ac.ir (M. Foroutan), goodarzisoroush@Gmail.com (M. Goodarzisoroush)

\section{To cite this article:}

Hamed Zohrehvand, Manouchehr Foroutan, Mohammadmehdi Goodarzisoroush. Effects of Mystical Literature on Islamic Architecture of Iran in Ilkhanid and Timurid Era. International Journal of Science, Technology and Society. Special Issue: Research and Practice in Architecture and Urban Studies in Developing Countries. Vol. 3, No. 2-1, 2015, pp. 107-111. doi: 10.11648/j.ijsts.s.2015030201.31

\begin{abstract}
Literature of every country includes a wide part of realities and social problems which are demonstrated in various forms. On one hand the correlation that exists between literature and the other hand arts led to influence of literature on other arts. Sufism can be regarded a valuable factor in Iranian society during Ilkhanid and Timurid which influenced on literature of that period and affected other arts such as architecture through various factors. Concepts, thoughts and influencing values should be identified and effectiveness should be reviewed in order to have a complete understanding of properties of Islamic architecture of Iran. The objective of this research is to review the effect of mythical literature as a factor for penetrating mystical values into architecture. In this research, at first properties of mystical literature were expressed by means of explanatory-historical method and by reviewing historical resources related to Mongolian era. Furthermore, effects of mystical literature in Islamic architecture of the era on approaches of training architects, architecture inscriptions and spread of fundamental concepts were demonstrated and discussed.
\end{abstract}

Keywords: Mystical Literature, Islamic Architecture, Iran, Ilkhanid and Timurid Era, Sufism

\section{Introduction}

Among arts, literature is one of the most important factors showing concepts available in society through vision to life. It can be regarded as a mirror in which ideals, thoughts and features of every society are demonstrated through language [1]. As effective concepts in Islamic society of Iran, the Sufism and teachings left unavoidable effect on literature of the country, especially during Mongolian era. In this age religious differences among different races made people tired of discussion, argument and rationalism and led them towards mystical and Sufi thoughts. Meanwhile blood and war made stricken individuals extremely poor and they were inclined to Sufism and monastery which had been a rich system in the era [2]. Iranian scholars turned to their inner world against these colonialisms and began to express their agonies and pains within framework of mystical literature [3]. Hence, Sufism and mystical literature were spread in this era and influenced on other arts like architecture. The objective of the research is to review effects of mystical literature on Islamic literature of Iran during Ilkhanid and Timurid eras due to penetration of Sufism into society. There has been little research on mystical literature and most of the research studies reviewed thoughts of a poem or writers regarding architecture and they refused to review this factor widely. In this research relationship of mystical literature with architecture was considered widely and from different aspects. To review this relationship, at first features of mystical literature and its growth were presented in this era and next its effects on different architecture aspects like training, decoration and fundamental concepts were reviewed. The word "Iran" in the article is cultural domain of Iran which encircled Transoxiana to Mesopotamia in that era.

\section{Mystical Literature Features}

Mystical literature is significant in Persian literature in terms of diversity and richness. The literature includes poetry and prose, philosophy and moral, history and biography, and prayer. But Sufism which originates from taste and inspiration is in agreement with poem, so that Sufism considers poem as a factor for expressing mystical concepts. However at first Sufis were not interested in poetry and regarded it null. But gradually poetry was spread from the first century by Abu-Saeid Abul-Khayr and his men in Iran [4]. During Mongolian era, the 
interest reached to its maximum level and individuals such as Attar, Jalal Ad-Din Muhammad Rumi, Shaikh Mahmud Shabistari, Saadi, Hafiz, Eraqi and Jami made Iranian mystical literature and poem reach to its peak so that it can be argued that the age was the most significant era of Persian poem and literature. The most important factor was penetration of Sufism into poem. One of the effects that poem and mystics literature left in Persian poem was a poem (like ode) which was recited for ordinary people and society. It is worth to mention that such a poem was only for praising great individuals such as nobles and courtiers. For example odes of Anvari were only for courtiers and bureaucrats (like the King Sanjar the Seljuq ruler of Khorasan) and they cannot be explained. There are abundant ceremonial expressions in this type of poem. But in mystical poem, poet notices ordinary people and this way the poem is considered as a mission which seeks to modify people's attitude and ethics. As a result it can be concluded that mystics presented literature to people through Sufis and publicized it. Of course this feature can be observed in poetry and in all literary forms. For example, if we compare Bayhaqi`s history with Attar's Tazkirat al-Awliya, we will find out that these two proses have key differences. Bayhaqi`s words has ode-like composition and it has difficult words which is hard for ordinary people to read. But when we do consider Attar's works, no difficulty can be found and the poem and prose both are simple. Poems of some poets such as Anvari and poets like him gradually become old insignificant and the opposite poems of Attar, Jalal Ad-Din Muhammad Rumi and Hafiz become more significant, because they are simple with wide concepts. This key feature made mystical literature penetrate into ordinary people's minds and it indicates mystical thoughts and teachings in art of society [5]. One of pleasant and influencing factors in literature of mystics and Sufis is being oral and closeness of their language to daily language of ordinary people [6]. This feature led to publication of mystical poem and literature among all social classes from scientists, scholars of religion and kings to ordinary people [7]. According to cases mentioned, effect of Sufism on poem and poetry, including a wide range of literature, can be demonstrated in following forms:

- Removing flattery due to avoidance of Sufis from this world and staying away from praising other people

- Avoidance of poems and poets from lust and using bad words in poems along with criticism

- Entrance of philosophy, wisdom and words to poem by poets of Sufis

- Emphasis on love, compassion, kindness and justice and avoiding from hatred

- Prevalence of Sufism expression in culture of poem and poetry

- Romantic, mystic and optimistic views towards all the creation

- Emphasis on knowledge and servitude of God and following Islamic without persistence and dealing with religious issues

- Expressing Sufi expressions within framework of poem as secret language [8]

Another effect of Sufism on literature in this era is establishing a language with new and mysterious expressions. Sufism and mystics used a special language for expressing their secrets and for exchanging their ideas. It is obvious that extraterrestrial concepts in Sufism world have not always been expressed within framework of clean and philosophical language. At this point we are encountering a wide range of symbols each of which focus on main reality of things in different levels. These expressions and symbols seem simple and folk, but they have deep concepts. In their works writers call this new language "language of senses". The language looks simple and folk, but it has a complex backend and influenced on literature of Iran greatly so that writers and poets of the next generation applied it abundantly. This type of inserting symbol and encryption influenced on different arts of the era such as miniature and architecture so that these mystical symbols were used in most of these arts [9].

\section{Supporting Mystical Literature in Mongolian Courts}

Ilkhanid and Timurid kings were mostly poet and poet catching. One of the reasons behind prosperity of literature in the era was interest of the kings, princesses and their support to scholars and poets. In Timurid era, not only Timurid kings were interested in poetry, but also they recited poems and memorized them, that's why Persian poem and prose were spread because of support of Timurid kings and princess [7]. But because of some unknown reasons, Mongolian kings supported mystical literature more than other literatures. Mongolian kings such as Ghazan khan, influenced by mysticism, converted to Islamic with the help of some mystics such as Sadr Al-din Hamû'î Jawiyni and that's why they praised Sufis and mystics [10]. Timur praised Sufi's Sheikh and finally as he mentioned in his will, he was buried near grave of an old mystics called "Mir Seyed Barkeh". Following their predecessors approach, other Ilkhanid and Timurid kings respected Sufis mystics and elders. Presences of mystics in the court are a factor of publication of mystical teachings among Mongolian rulers. For example Ala al-Daw'la Semnani and his father were both in the Ilkhans ambitions and they influence so that their recommendations on policy were applied. Loving Arts minister of Sultan Hussain Bayghrā Amir Ali-Shir Navā'i himself was Sufi and had close relationship with Jami, great mystic and Poet. Shah Nematollah Vali was also one of the rulers of his time [2]. Generally, penetration and validity of Sufis and mystics among ordinary people made Mongolian kings support mystics and their poems in order to maintain and increase their own validity among people.

\section{Effect on Training of Islamic Architects}

One of the reasons behind communication of mystical literature with Islamic architecture in this era is effect of "Futuwwatnameh"(chivalry method book) as training literature and effect of mystical chivalry on training of 
architects along with other craftsmen. Method of traditional training of architecture of Iran was based on practical methods in form of student and master and they were conducted mainly by guilds and in this method effect of Futuwwat (chivalry method) costumes is significant.

Main aspects of Futuwwa customs are close to steps of Sufi principles and it was spread from the half of the sixth century on among artists and craftsmen widely [11]. It penetrated into society and according to Ibn Memar, Al-Naser (Abbasid Caliph) Joined to Futuwwat at the begging of the seventh century and rules it in Muslim community [12]. Futuwwat (chivalry method) can be regarded moral and mystical manner which is part of mysticism manner, since it is based on edification and training characteristics and moral virtues [13]. Futuwwatnameh is a dissertation or book which talks about fair attitude, opinions, and rules. Futuwwatnameh forms a significant part of folk literature of Iran and represents culture of Iran's folk in the past [14].

Moreover, oral aspects these Futuwwatnamehs have social aspects and they influence on different guilds and professions directly and this led to penetration of mystical poems into their works. Among their poetry and prose, many of Sufism kings wrote some books called Futuwwatnameh [15].

Futuwwatnameh from guilds can be considered as the most valuable and interesting ones in which the way of penetration of Futuwwat principles into professions of Iran's land in the era is introduced. Every guild in that era had its special Futuwwatnameh. This book prescribed a type of mortification, praise and noticing to world of sense where even ordinary people with simple professions were influenced by these mystical and moral concepts [16].

One of features of Futuwwatnameh's texts is its mysterious tone. In all of these books, principle of sustainability is clearing heart from world opacity (evils) and combining of every deed with heart praise, since they deeply believed that form of everything represents its nature. According to effect of mystical concepts in these books, inner praise is mixed with our deed every moment. Equipment and tools for working in Futuwwatnameh is an allegory from heaven and each of them suggest inner concept which makes secret-writing, equipment and tools significant. The result of this mysterious style in training texts and architectural principles can be regarded as a kind of communication between appearance with divine and transcendent concept.

Generally, effect of Futuwwatnamehs on different guild especially architecture can be summarized as follows:

- The industries and arts they owned were divine integrity and they link it to sacred origin.

- The precondition of entering industries and profession is adornment and politeness and the next precondition was chivalry and clearing from any improbity.

- Establishment from the beginning to the end should be followed by praising God and heart praising should be mixed in an allegorical form.

- The aim of work should be closeness to God.

- Student should avoid bad habits and pessimistic, egotistical and pride, and materialistic and should be prepared for understanding truth and mysteries.

- Masters and veterans had a great position in all of their professions and spiritual presences of master and elderly is necessary [17].

It can be understood that Futuwwatnameh as a type of mystical folk literature has had a significant effect on guild community; it effected architecture profession and art in which science is mixed with wisdom and Spirituality.

\section{Mystical Literature as the Inscription on Architecture}

Moreover its narrative feature, literature of Iran especially Persian poem has always been a tool for expressing different concepts and notions such as concepts of legal, mystical, praise, and descriptions. Meanwhile in architecture of Iranian structures, even the smallest elements have certain concepts which relate it with society of that era. Since poems are considered as inscription fitting with special place and with a fluent language, they transfer artists`concepts and thoughts to viewers. Before these eras, Quran was used as an inscription and for decoration but in this era and with spread of mystical literature, mystical poems were used asinsription in architecture. Buildings of this era are decorated to inscriptions including mystical concepts and we can mention buildings of Shah-zendeh complex, Dodar School (madrasa), Shah Mosque in mashhad, Darb-e imam Isfahan Shrine, Kashan Square Mosque, Ghalvar Mosque in Herat and Tomb of Poria-vali in which concepts of poems are in good agreement with the site of architecture [18].

For example in Ghalvar Mosque (Fig.1) which is located in west of Herat, there is an inscription of mosaic on the wall against sanctuary of the mosque which has three rows written in Sols style (a kind of calligraphy style). The text of the inscription is Golestan-Saadi suggesting this world is mortal and good and evil deeds of men are sustainable and in the end the year of construction is mentioned.

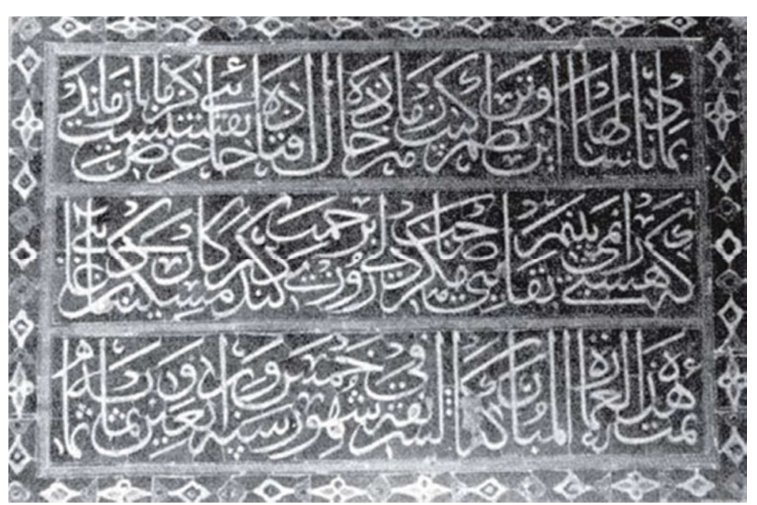

Figure 1. Inscription of Ghalvar Mosque in herat [18].

In the mosque of Kashan square (Fig. 2), some inscriptions can be observed in Sols writing from Rumi poems which express top position of men against God and mystics has always noticed this. Tomb of Pourya-ye vali which reminds us chivalry in Iranian culture is another building on which some 
quatrain of Pourya-ye vali (type of poem) can be found which all has wisdom and mystical concepts. This quatrain has some advice which recommends men to stay away from fools and effort for better life (Fig. 3).

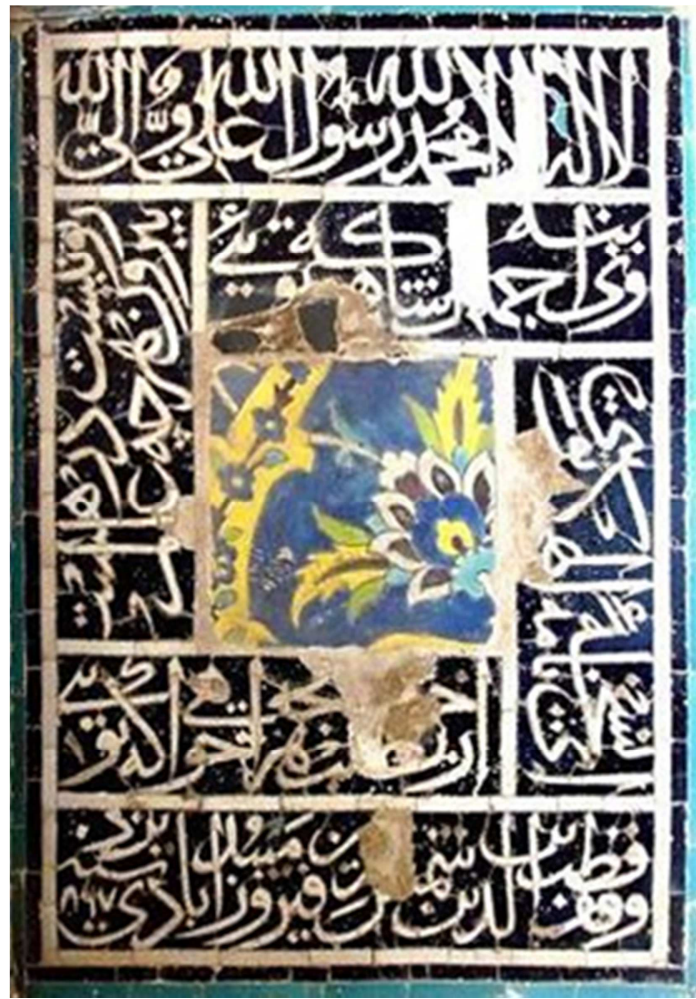

Figure 2. Inscription of square mosque in Kashan [18].

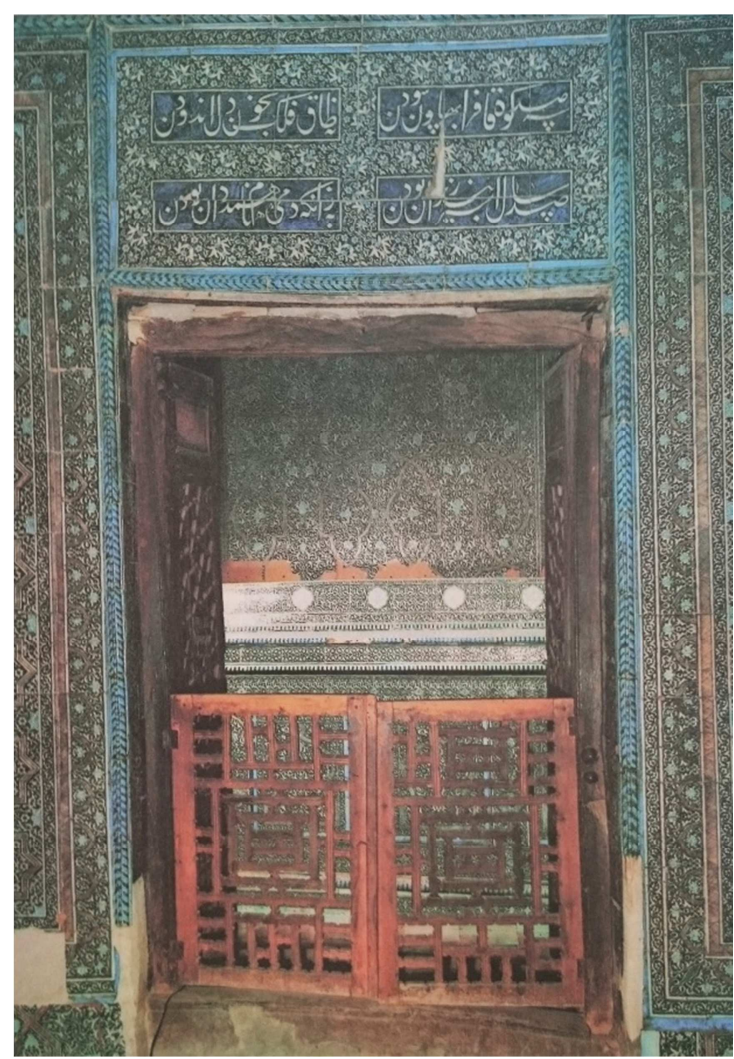

Figure 3. Inscription of tomb of Pourya-ye vali [7].
In following table (Table. 1) some architecture buildings along with name of poets were collected in which mystical poems had been used as inscription:

Table 1. Buildings with Mystical poem inscription.

\begin{tabular}{ll}
\hline Buildings with Mystical poem inscription & Name of poet \\
\hline Dodar school in Mashhad & Saadi \\
Ghalvar mosque in Herat & Saadi \\
Shah mosque in Mashhad & Hafiz/ Ghasem Anvar \\
Darb-e imam shrine in Esfahan & Saadi \\
Square mosque in Kashan & Rumi \\
Tomb of Pourya-ye vali & Pourya-ye vali \\
\hline
\end{tabular}

\section{Architecture Features from Aspect of Mystical Literature}

The places men established for living originate from thoughts of authors. Aside from the relationship between body of buildings and culture and thoughts of authors and their effectiveness, wisdom testifies a link between these two. Mystic literature as a factor which produced new values in society during Ilkhanid and Timurid era, established certain values and features on architecture of these eras. Considering key books of great poets such as Jalal Ad-Din Muhammad Rumi, Hafiz and Saadi it can be learnt that among their own training and mystical stories, they conceived certain features for suitable architecture. From view of great mystic writers, features creating architecture are significant. For example Rumi considers self-purification the most important necessity in producing appropriate place [19]. Therefore, actions and circumstances of men influence on their world outside. From view of Rumi, it was because of evil inner of those built Zerar mosque which made it filthy and Prophet Mohammed as God ordered him to devastate it. It had a clear form, while its nature was filthy, since those built it were filthy. In contrast, Prophet Abraham had a clear intention in making God's house (Kaaba) and Solomon in building Al-Aqsa Mosque. This clearance was clear in thriving form of the mosques. Rumi argues goodness of Kaaba is not from body of building, it does come from tits clear heart of architect [20].

Mystics consider all creators should praise God and they believe that beings all follow orders of God. It can be argued that recognition, ordering and praising God means that everything in this world turns to what God asks. Therefore another intellectual feature for appropriate place from view of mystics is talent of the place for praising God, something which is demonstrated in mystical literature. For example Rumi continuously warns that real homeland of men is another place and appropriate architecture should remind us our real homeland. Rumi considers the word "places" reflection of "Yaar (God)" [20].

According to Rumi, architecture industry is the industry of mixing wisdom with soil and architect where soil is enriched with wisdom. Architects have learnt how to measure good locations in imagination, hence precondition of establishing a good location for an architect is using wisdom and science 
"This soil turned to good location due to closeness to wise"[20].

Mystics agree with simple architecture and they oppose luxurious architecture. One of the samples is easy graves which according to Rumi they are not suitable for men of God, since real development of grave is obtained only through clearance of heart [22]. For example someone tried to make a Tomb on grave of Rumi s father and Rumi did not allow him saying: "Because there is no better than the dome of the sky, so be satisfied to roof of sky" [21].

In following table (Table.2), features of good architecture from aspect of mystic literature are summarized:

Table 2. Features of good architecture from aspect of mystic literature.

\begin{tabular}{ll}
\hline & Architects`purity and \\
& self-purification \\
& Intention of creator \\
Features of good architecture from & Place`s talent for raising God \\
aspect of mystic literature & Using wisdom and science in \\
& making building \\
& Simplicity of building \\
\hline
\end{tabular}

\section{Discussion and Conclusion}

With the invasion of Mongolians to Iran a key chapter of Sufism history began which was a turning point in history of Iran. Respect of Mongolian kings and closeness of their religion (shamanism) to some principles of Sufism on one hand and more caring of people to Sufism for facilitating pains (due to sustainability of disasters and devastation of religious powers during Abbasid Caliph) on the other hand spread Sufism in society. As a result mystical ideologies were reflected in literature art and established mystical literature. Mystical literature is a strong link which joins Iran's culture and art and led to solidarity of different arts like the architecture.

According to this, mystic literature can be regarded as a tool for transferring mystic concepts to architecture. Its effect in architecture is clear on the way of teaching architect in the era, on mystic inscriptions in architecture decorations and prescription fundamental concepts of good architecture.

So that Futuwwatnameh as a kind of mystical literature had a clear role in raising moral features of architect. Mystic poems were used in the era as inscription and the concepts were fully in agreement with type of architecture applied. Also mystic literature taught some principles such as intention of architect on final work, talent of architecture for praise of God, significance of wisdom and simplicity of architecture.

\section{Acknowledgements}

The article is from MA thesis of Hamed Zohrehvand titled "Investigation the Effect of the Mysticism of the Iranian Islamic Architecture in Tomb Complexes of Azeri's Style "approach guided by Dr, Manouchehr Foroutan in Islamic Azad University, Hamedan Branch.

\section{References}

[1] M. Shafiei Kadkani, With Lights and Mirrors, Tehran: Sokhan Publication, 2011.

[2] P. Jackson and L. Lawrence. The Cambridge History of Iran: The Timurid and Safavid Periods, vols.6, Cambridge: Cambridge University Press, 1986.

[3] Z. Safa, Transformation History on Persian Poetry and Prose, Tehran: Amir Kabir Publication, 1965.

[4] A. Zarrinkub, Soofieh Legancy Value. Tehran: Amir Kabir Publication, 1996.

[5] B. Foruzanfar. Literary History of Persia. Tehran: Khojaste press, 1997.

[6] A. Raazi. "Features of Mystical Shams Language". Journal of Literature and Humanities, no.160, 1989, pp.200-214.

[7] H. MirJafari, History of Political, Social, Economic and Cultural Development Timurid and Turkmen, Tehran: Samt publication, 1991.

[8] SH. Nomani, Shi'r al-`Ajam, Translated by T. Gilani, Tehran: World of Book, 1989.

[9] A. Zarrinkub, Search in Sufism, Tehran: Amir Kabir Publication, 1987.

[10] M. Khwandamir, Habib al-Sīyar, Tehran: khayyam publication, 1944.

[11] Y. Zaka, Architects and craftsmen in Islamic period, Tehran: Samt Publiction, 1991.

[12] M. Ibn Memar, Al- Futuwwa. Baghdad: Balaq, 1948.

[13] H. Ghodosifar, "Traditional Education in Architecture and Evaluate it from the Perspective of Brain-based Learning", Journal of Architecture of Iran, no.1, 2012, pp. 39-58.

[14] M, Afshari, Futuwwatnameh va resaeil Khaksaryeh, Tehran: Institute for Humanities and Cultural Studies, 1989.

[15] E. Hakemi, Principles of generosity and chivalry, Tehran: Asaatir, 1989.

[16] A. Khan Mohammadi. Futuwwatnameh of Architecture. Journal of Sofeh, no. 5, 1992, pp. 32-45.

[17] H. Nadimi, Chivalry of Architects: Study of Futuwwatnameh, Proceedings of the Congress Architectural History, Tehran: Cultural Heritage, 1985.

[18] M. Shayeste far, "Architectural and Persian Poetry Interaction in Timurid and Safavid Era Buildings". Journal of Islamic Art, no.11, 2009, pp.79-104.

[19] Shams Al-Din Mohammad Tabrizi, Articles of Shams, Correction by M. Movahed, Tehran: Kharazmi Publication, 2006.

[20] J. Rumi, Masnavi, Tehran: Ghatre Publication, 2007.

[21] SH. Aflaki, Managheb Al-Arefin, Tehran: World of Book, 1983.

[22] H. Pishvaei, "Soil and Wisdom: Study of Architecture in Masnavi", journal of Architecture of Iran, no.3, 2013, pp.42-54. 